
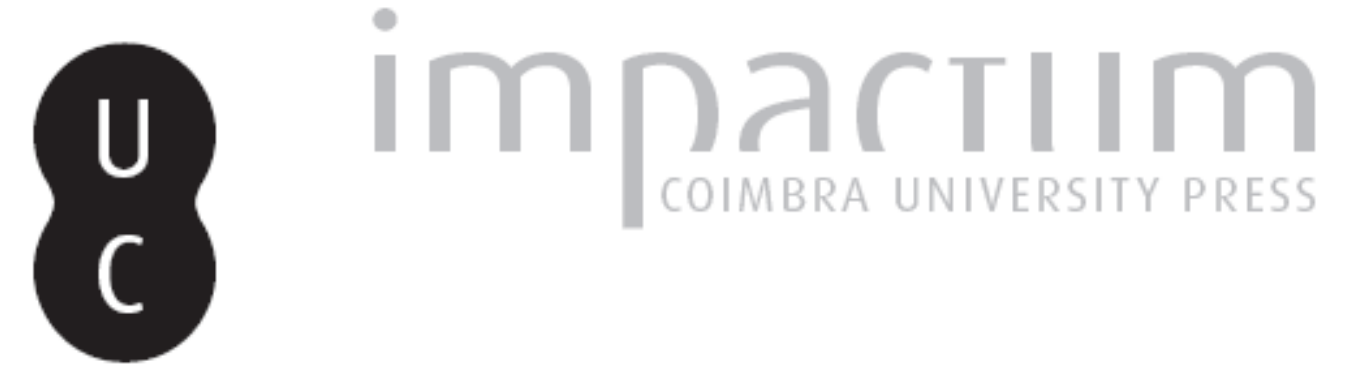

The possibility of knowledge according to Plato

Autor(es): $\quad$ Gerson, Lloyd P.

Publicado por: Imprensa da Universidade de Coimbra

URL persistente: URI:http://hdl.handle.net/10316.2/42250

DOI: $\quad$ DOI:https://doi.org/10.14195/2183-4105_4_4

Accessed : $\quad$ 26-Apr-2023 06:46:54

A navegação consulta e descarregamento dos títulos inseridos nas Bibliotecas Digitais UC Digitalis, UC Pombalina e UC Impactum, pressupõem a aceitação plena e sem reservas dos Termos e Condições de Uso destas Bibliotecas Digitais, disponíveis em https://digitalis.uc.pt/pt-pt/termos.

Conforme exposto nos referidos Termos e Condições de Uso, o descarregamento de títulos de acesso restrito requer uma licença válida de autorização devendo o utilizador aceder ao(s) documento(s) a partir de um endereço de IP da instituição detentora da supramencionada licença.

Ao utilizador é apenas permitido o descarregamento para uso pessoal, pelo que o emprego do(s) título(s) descarregado(s) para outro fim, designadamente comercial, carece de autorização do respetivo autor ou editor da obra.

Na medida em que todas as obras da UC Digitalis se encontram protegidas pelo Código do Direito de Autor e Direitos Conexos e demais legislação aplicável, toda a cópia, parcial ou total, deste documento, nos casos em que é legalmente admitida, deverá conter ou fazer-se acompanhar por este aviso. 


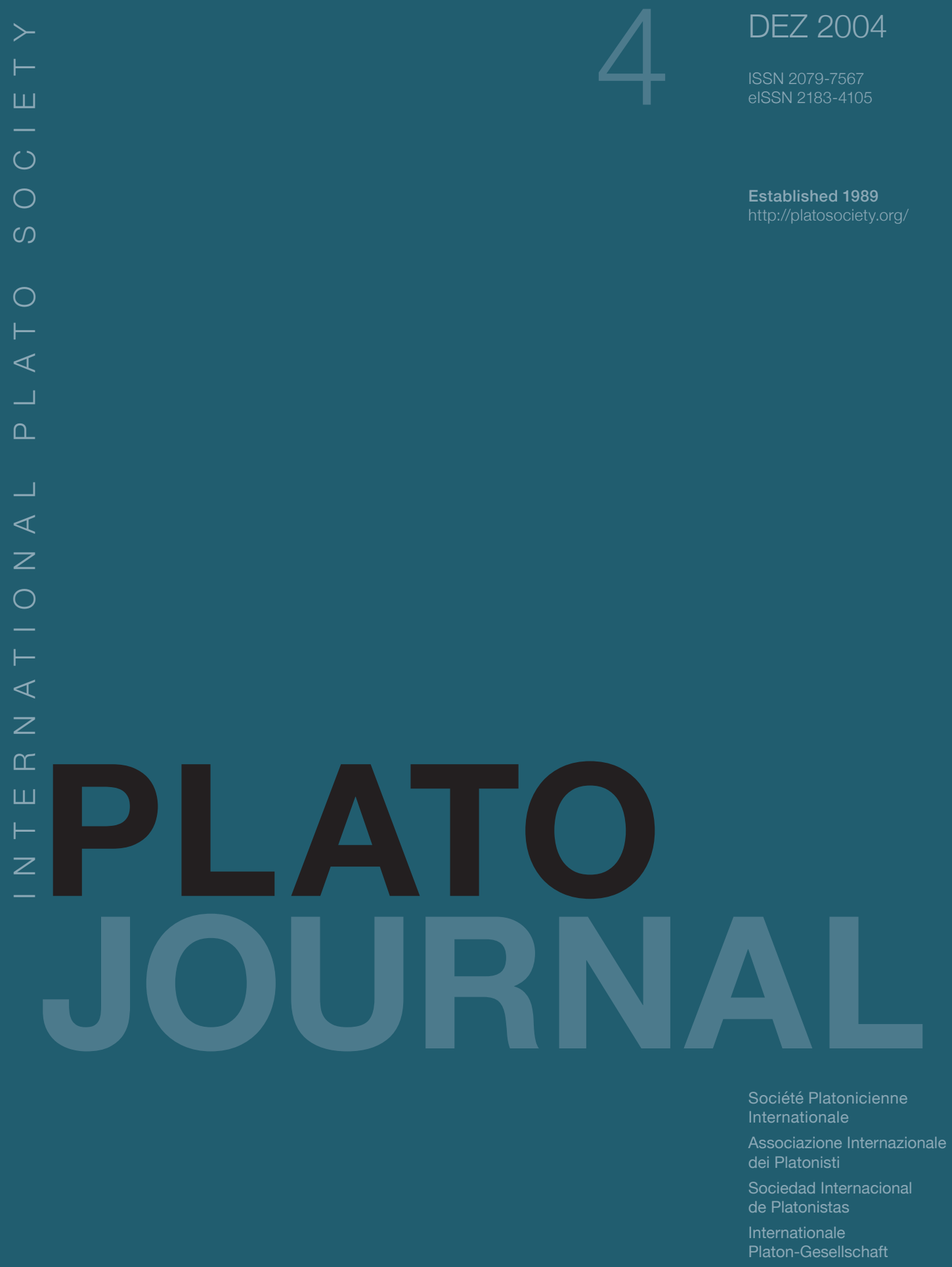




\section{The Possibility of KNOWLEDGe AcCORding to Plato}

I interpret the question 'is Platonic knowledge an illusion?' as a question about the possibility of knowledge. The latter question is full of complexities and interest, as I hope to show. First, however, we need to appreciate what knowledge or, more exactly,

The two texts that are especially important for understanding Plato's

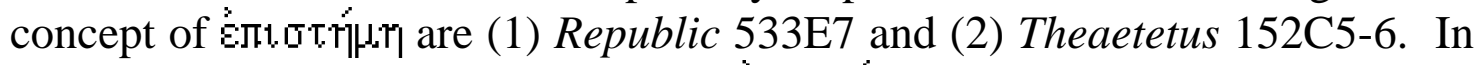
the first passage, Plato stipulates that section of the upper portion of the divided line. In the second passage, he offers the criteria that sense-perception must meet it is to be counted as knowledge, that is, 'it must (a) always be of what is and (b) be ousvets or 'without falsity'. I start with these criteria for knowledge.

There are several points. First, these criteria are evidently defining criteria, in which case they are, together, necessary and sufficient for knowledge. Second, the question of whether the criteria could be independently satisfied (so that there might be cognition of what is though it not be without falsity or that there be cognition that is without falsity though not of what is) depends on resolving the ambiguities in their meaning. Is the term 'what is' intended to refer to what Plato elsewhere means by that which 'really is', i.e., intelligible reality or does it include that which is in any sense even if it is not what 'really is'? Is the term ousubic to be understood as (a) equivalent to 'true' such that it is met by a belief that is stipulated to be true or (b) as equivalent to 'incorrigible' such that it is met by cognition where correction is impossible though the possibility of error remains or (c) as equivalent to 'infallible' such that it only pertains to cognition entailing the impossibility of error?

It is hardly surprising to discover that Plato plays with these ambiguities, especially in Theaetetus. Thus, for example, true belief and sense-perception are 'without falsity' in senses (a) and (b), respectively, though they are eliminated as candidates for knowledge. There is, however, one overriding reason for thinking that when offering defining criteria for knowledge, Plato means by 'what is' 'what really is' and by 'without falsity' 'infallible cognition'. The reason is that only if he understands these criteria in these ways are the criteria not independently capable of satisfaction. That is, 
only if 'what is' means 'what really is' and only if 'without falsity' means 'infallible' does it follow that it is not possible to have knowledge of what is without it being infallible and it is not possible to have infallible cognition of other than what really is.

Why should the mutual implication of the criteria matter? Because if they do not mutually imply each other, then there is no rationale for these being the defining criteria. It would just happen to be the case that knowledge is of what is and without falsity. Such adventitiousness is perfectly acceptable when criteria are stipulative; it is a sheer embarrassment when the criteria are supposed to be defining. And I would hardly know how to begin to respond to someone who claimed that when Plato lays down criteria for knowledge, he is merely telling us how he proposes to use the word or the concept rather than what he understands the thing knowledge to be.

In fact, the separation of belief or Boto and knowledge in Republic (476Aff) strongly supports the interpretation of the criteria as mutually implicatory. There is no belief of the objects of knowledge or knowledge of the objects of belief precisely because if there were, then the criteria could be independently satisfied. That is, if knowledge and belief were not mutually exclusive, then we could have both belief and knowledge of what really is, and belief and knowledge of what is not what really is, which would mean that we could have both infallible and non-infallible cognition of the same thing. ${ }^{1}$

The reason why the criteria are mutually implicatory is this. Infallible cognition means that if ' $\mathrm{s}$ ' is the knower and ' $\mathrm{K}$ ' is knowledge and 'o' is the knowable, then 'sKo' entails 'o'. That is, the presence of the cognitive state that is knowledge entails that what is known is what that cognitive state takes it to be. Stated otherwise, if someone has Platonic knowledge, then what is

'Cf. Rep. 477E6-7 where (cvouspropoc). Men. 98A1-8 is sometimes taken to imply that knowledge is true belief plus some sort of justificatory explanation. In reply, we should recognize, first, that Republic and Theaetetus probably represent an advance over Meno in Plato's thinking about knowledge. Second, the transformation of true belief into knowledge is not even in Meno explicitly said to indicate knowledge about the same object about which there is true belief. 
known cannot possibly be other than what it appears to be to the knower. This is a very strong criterion, indeed. It could not possibly be met if the objects of knowledge could be other than as they appear to be to a knower.

One might reply that the very objectivity of that which really is guarantees that it could be other than as it appears. Not exactly. It is true that what really is could be other than what it appears to be if appearance is taken as non-identical with being. But the exclusion of belief from the realm of the knowable means that Plato does not take it in that way. What really is could not, in fact, be other than as it appears to be to the only subject who can possibly cognize it, namely, a knower. Thus, there is no cognitive space for the appearance, as opposed to reality, of the knowable.

In order for the entailment relation between knowing and being to work, the state of knowing and the knowable object must be such that the existence of the state guarantees the achievement of knowledge. The guaranteeing, of course, has to be self-guaranteeing, that is, knowledge has to be a self-evidential state. What this means, roughly, is that knowing is being in an incorporeal state in which the intentional object is an incorporeal entity whose entire being is 'exhausted', as it were, in being that intentional object. It is analogous to the intentional object of certain perceptual states in which the entire being of the object, say, feeling headachy, is exhausted by the intentional state. I say 'analogous' and not 'identical' because headachy states, unlike that which really is, are entirely relative to their perceivers. They do not have the objectivity that reality, for Plato, implies. We can here see the intuition behind the claim in the so-called Affinity Argument in Phaedo (78B4-84B4) that the knower must be like the known. The knower must not merely be the same sort of thing as the known; it must also constitute the known by knowing. This is, presumably, what the Demiurge or divine Intellect is supposed to do.

The stringent requirements for knowledge are what lay behind Plato's insistence that knowledge is found only at the top section of the upper portion of the divided line. Knowledge cannot, on this reading, be propositional or discursive for the simple reasons that propositions are not among the things that 'really are' and discursive thinking is entirely representational. What is sometimes called 'dialectical knowledge' in Plato is no such thing.

For dialectic is a 'power' or Bivous (Rep. 511B4); it is only the 'grasping' of 
the knowable afforded by dialectic that could be knowledge.

If knowledge is what Plato takes question whether such a thing is possible. Plato's answer to this question is not, I think, to insist that ab esse ad posse. That is, I do not think he anywhere argues that he has knowledge or does anyone else, at least occurrently. Of course, if knowledge is what Plato says it is, then thirdperson knowledge claims are entirely parasitic on first-person knowledge claims, so it would be pointless for Plato to make such claims about others or even to make such claims about himself, since for us his own claims would only be third-person. This, by the way, helps explain the entire heuristic strategy of writing dialogues rather than treatises wherein one pronounces what one supposedly knows.

The answer to the question Plato does give is extraordinary. It is found in Phaedo in the so-called Recollection Argument (72E3-78B3). This is not an argument that we do occurrently know Forms. It is an argument that if we did not at one time know Forms, then it would not be possible for us to make certain judgments about sensibles now. It is a sort of transcendental argument to the effect that our having had knowledge is a condition for the possibility of our making judgments, specifically, about the diminished intelligibility of instances of Forms. And as the so-called Affinity Argument (78B4-84B4) goes on to show, this knowledge (that we must have had but to which we do not now have direct access) would only be possible for us if we were like that which is knowable, only if we are incorporeal entities.

The force of these two arguments is not generally appreciated, largely because they are taken to be nothing more than (bad) arguments for the immortality of the soul. This is unfortunate. Plato is, if I may summarize, making a profound claim about cognition in general. He is claiming that the judgments that we unquestionably do or can make could only be made by subjects who could not be merely corporeal. This is a claim that challenges the notion that all 'higher' cognition, that is, all cognition above senseperception, can be given a naturalized explanation along the lines of current neuroscience or cognitive science research.

In Theaetetus (197B8-10) Plato introduces the distinction between

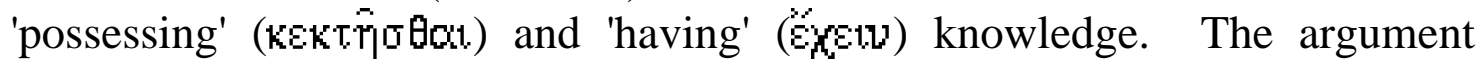
reveals that there is no such thing as possessing knowledge, or at least that 
possessing 'facts' or 'propositions' is not knowledge in the primary sense, largely because if it were, then, counterfactually, false beliefs would not be possible when one 'possessed' these facts or propositions. What 'having' knowledge adds to 'possessing' knowledge is something like the occurrent awareness of what is known. But this awareness is not merely awareness of the 'content' of what is known. It is awareness of the presence of the content in the identical subject who is aware of its presence. In short, it is selfreflexive awareness. And this is only possible for an incorporeal entity. This is, incidentally, exactly the same point Aristotle makes in De Anima, book three (429b6-9), when he distinguishes the potential knowing that is the presence of form in the intellect from actual knowing. As Aristotle says, in actual knowing one knows oneself.

That knowing is self-reflexive helps explain why infallibility belongs to knowing and, indirectly, why what is knowable must be incorporeal, too. There is infallible awareness of 'possessing' the knowable because what I am aware of is a content. It is impossible that the knower should be aware that he is in the state he is in without being in that state. But that state that he is in is identification with the object known.

So, the possibility of knowledge, according to Plato, rests upon knowers being incorporeal entities. This knowledge may not, in fact, be possible for such knowers when they are embodied. In addition, this knowledge is not reducible to a representational state, though cognitive states that do represent would not be possible if knowledge were not possible. Many if not all contemporary philosophers would, I suppose, hold that since human beings are not incorporeal entities, knowledge, as conceived of by Plato, is, therefore, not possible. If knowledge so conceived is not possible, then either knowledge is something else or the word 'knowledge' may be used stipulatively for some other type of cognition, say, justified true belief or perhaps just true belief. But if infallibility is thus implicitly excluded from the criteria for the possession of knowledge, then it is possible to countenance such logical monstrosities as 'I know, but I may be mistaken.' And the justification for knowledge claims is unequivocally severed from truth. For being justified in one's belief could never entail that what one believes is true, especially if it is propositions that are supposed to be the locus of the knowable.

Lloyd P. Gerson University of Toronto 